\title{
Families' Financial Stress \& Well-Being: The Importance of the Economy and Economic Environments
}

\author{
Terri Friedline $^{1} \cdot$ Zibei Chen $^{2} \cdot$ So'Phelia Morrow $^{1}$
}

Published online: 15 July 2020

○) Springer Science+Business Media, LLC, part of Springer Nature 2020

\begin{abstract}
The Great Recession and the unfolding COVID-19 Pandemic Recession - two major disruptions to the economy that occurred just one decade apart-unequivocally confirm the importance of the economy and economic environments for understanding families' financial stress and well-being. However, recent published literature places too little emphasis on the economy and economic environments and instead focuses on explanations rooted within individuals and families. In this article, we review research on families' financial stress and well-being published in JFEI between 2010 and 2019, which analyzed data collected during the Great Recession and were subsequently published in the shadow of the economic downturn. We discuss the economy and economic environments as gaps in the literature and encourage future research to focus on these explanations of stress and well-being, especially in response to the pandemic recession.
\end{abstract}

Keywords Financial well-being $\cdot$ Financial stress $\cdot$ Great recession $\cdot$ Capitalism $\cdot$ Economy

\section{Introduction}

As one of the most significant macroeconomic events of the last century, the Great Recession that began in 2007 undermined the financial well-being of millions of American families. This widespread economic downturn disrupted families' financial well-being, defined as being able to "fully meet current and ongoing financial obligations" (Consumer Financial Protection Bureau [CFPB] 2015, p. 18 , when banks' and financial institutions' predatory and subprime lending precipitated the foreclosure crisis and

This is one of several papers published together in Journal of Family and Economic Issues on the "Special Issue on Virtual Decade in Review".

Terri Friedline

tfriedli@umich.edu

Zibei Chen

zibeic@umich.edu

So'Phelia Morrow

sopmarie@umich.edu

1 University of Michigan School of Social Work, $1080 \mathrm{~S}$. University Avenue, Ann Arbor, MI 48109, USA

2 University of Southern Mississippi School of Social Work, Hattiesburg, USA forced families into borrowing debt (Mian and Sufi 2014; Federal Reserve Bank of New York 2019). The extraordinary rise in subprime mortgage lending precipitated the equally extraordinary rise in default rates: Nearly 4 million homes were foreclosed at the height of the Great Recession (Mian and Sufi 2014). Suggestive of their need to cope with economic hardship, families increased their borrowing in the years after the economic downturn. Total consumer debt rose from approximately $\$ 7$ trillion in 2003 to $\$ 12$ trillion in 2008 and \$14 trillion in 2019 in inflation-adjusted dollars (Federal Reserve Bank of New York 2019). These effects were experienced more acutely by those who were targeted by banks and financial institutions for subprime lending and that had the fewest financial resources to spare, including Black and Brown families (Faber 2018; Hamilton and Darity 2017), lower-income families (Pfeffer et al. 2013), and families headed by women (Baker et al. 2019).

The effects of the recession precipitated by the global pandemic in 2020, caused by the rapid spread of the coronavirus COVID-19, will be far more severe than those of the Great Recession. American families never fully recovered from the Great Recession to begin with, as evidenced by continued rising consumer debt and wealth losses (Baker et al. 2019; Federal Reserve Bank of New York 2019; Hamilton and Darity 2017). Without strong and aggressive government intervention, families are likely to be completely 
financially devastated by the unfolding Pandemic Recession. It will be years and decades before the full, lasting effects of the Pandemic Recession on all aspects of life are understood; however, early reports of families' lived experiences are already revealing their immediate financial devastation. While the lessons that are still being gleaned from the Great Recession can inform current and ongoing responses to the Pandemic Recession, much more extensive and grassrootsfocused policy responses will be needed to stabilize and shore up families' financial well-being.

Since its inception in the late 1970s, the Journal of Family and Economic Issues (JFEI) has been dedicated to the important academic mission of exploring and understanding families' financial well-being within the contexts of their economic environments. The journal's literature published within the most recent decade- a time period that encompasses the Great Recession-continues this legacy and has made important contributions on a range of topics including income, wealth, and debt (Addo et al. 2019; Fan and Chatterjee 2019; Hancock et al. 2013), economic hardship (Lucero et al. 2016; Schieman and Young 2011), financial stress (Kramer et al. 2019; Valentino et al. 2014), and strategies for coping with hardship, like saving money (Fisher and Montalto 2011; Fontes 2011; Haron et al. 2013).

At the same time, we contend that recent published literature on families' financial stress places too little emphasis on economic environments and, by extension, the economy (Friedline, Nam et al. 2014; Lai 2011; Rauscher and Elliott 2016; Thorne 2010; Vesely et al. 2015), and often focuses on explanations rooted within individuals and families (Deidda 2015; Gjertson 2016; Park and Kim 2018; Romo 2014; Stein et al. 2013; Tobe et al. 2016; Valentino et al. 2014). This lopsided emphasis is common for articles in journals whose scope is similar to that of JFEI, such as journals focused on family or household finance, counseling, and planning. The effects of Great Recession and the unfolding COVID-19 Pandemic Recession on families' financial well-being-two major disruptions to the economy that occurred just one decade apart - should unequivocally confirm the importance of the economy and economic environments. The gaps created by the focus of JFEI's recent published literature provide opportunities for the journal to extend its mission and focus on the economy and economic environments in which families are situated.

In this article, we review research broadly captured under the umbrella of financial stress and published in JFEI between 2010 and 2019, and which were mostly conducted in the United States. These 23 articles were assigned to us by the special issue editors to focus on financial stress. The articles analyzed data collected during the Great Recession and were subsequently published in the shadow of the economic downturn. Therefore, a focus on the economy (national and global macroeconomic sites of labor, production, and consumption) and economic environments (local and regional economic sites) is even more consequential. We discuss these gaps in the literature and encourage future research on families' financial stress and well-being to emphasize the economy and economic environments, especially in response to the Pandemic Recession.

\section{A Literature Review of Financial Stress and Well-Being}

The literature we reviewed that broadly focused on financial stress and well-being can be grouped into four categories: income, wealth, and debt; economic hardship; financial stress; and coping strategies. We attempted to create a temporal ordering of families' financial stress by grouping the literature into these categories. For example, families with inadequate income, wealth, or debt may experience economic hardship that precipitates stress when they struggle to afford their current and ongoing financial obligations. Families use a variety of strategies to cope with these circumstances. Table 1 lists these articles and provides a summary of their research questions and main findings. Given that these articles covered broad and overlapping topics, several were grouped into multiple categories.

\section{Income, Wealth, and Debt}

The Great Recession weakened the financial well-being of many families, placing them at risk by destabilizing incomeproducing and wealth-generating mechanisms (Friedline et al. 2014; Lee and Kim 2018; Rauscher and Elliott 2016; Rhine et al. 2016). Families experienced significant changes or disruptions to their income, wealth, and debt during and after the economic downturn (Federal Reserve Bank of New York 2019). One basic way that families attempted to establish and maintain their financial well-being was through savings account ownership (Rhine et al. 2016). Savings provide families with liquidity for supplementing their income and making further investments. Those with savings accounts were able to take better advantage of these assets for buffering against some of the negative effects of the economic downturn (Friedline et al. 2014); although, families who were positioned to take better advantage of these assets benefitted from intergenerational wealth transfers (Friedline et al. 2014; Rauscher and Elliott 2016).

One way families tried to maintain their financial wellbeing in response to the Great Recession was through opening lines of credit and applying for small loans. However, families' participation in these types of wealth-building and debt accumulation mechanisms was restricted to those who were able to participate in lower-cost, higher quality financial services. Instead, many families used higher-cost, lower quality financial services like payday, installment, and 


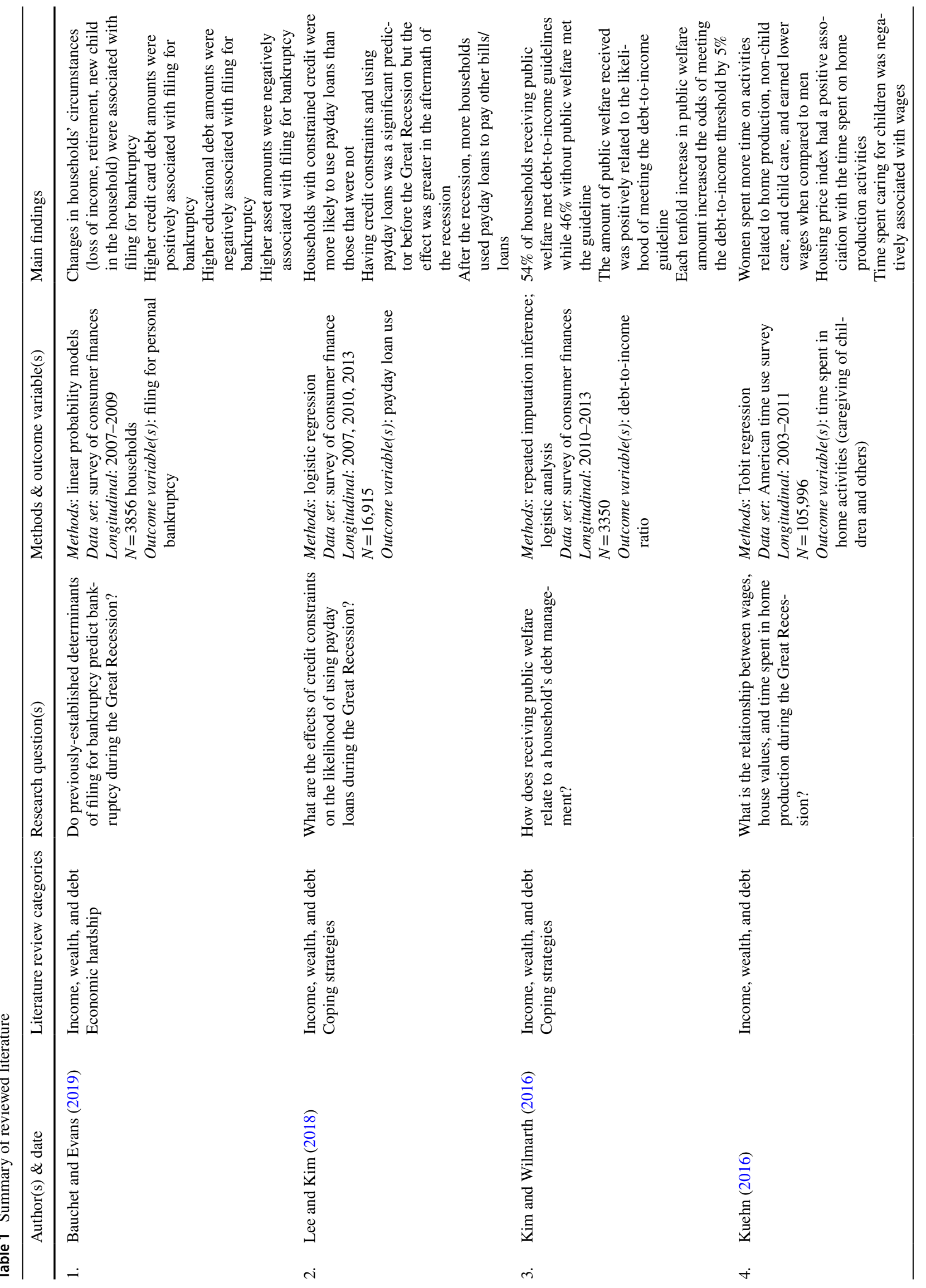




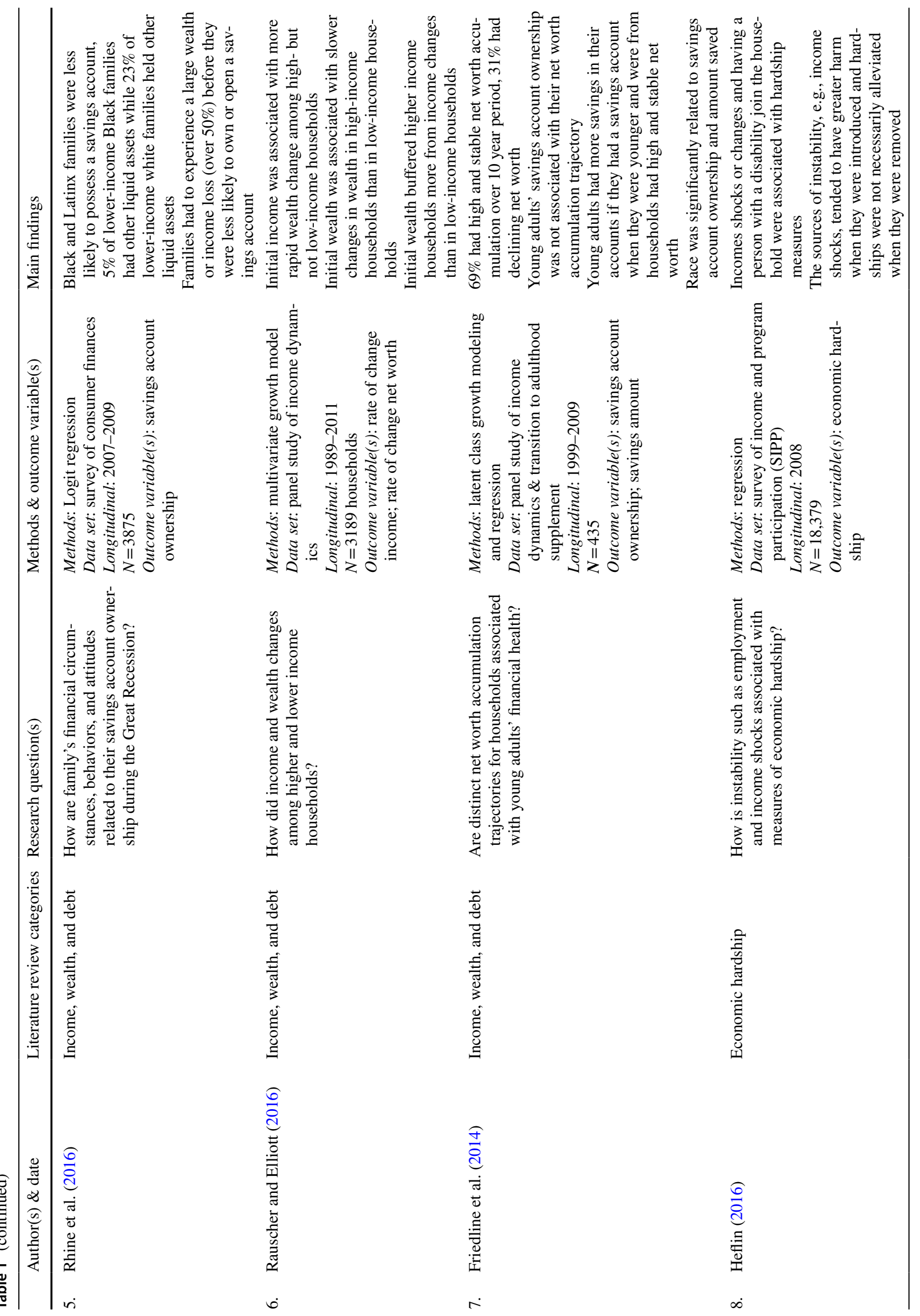




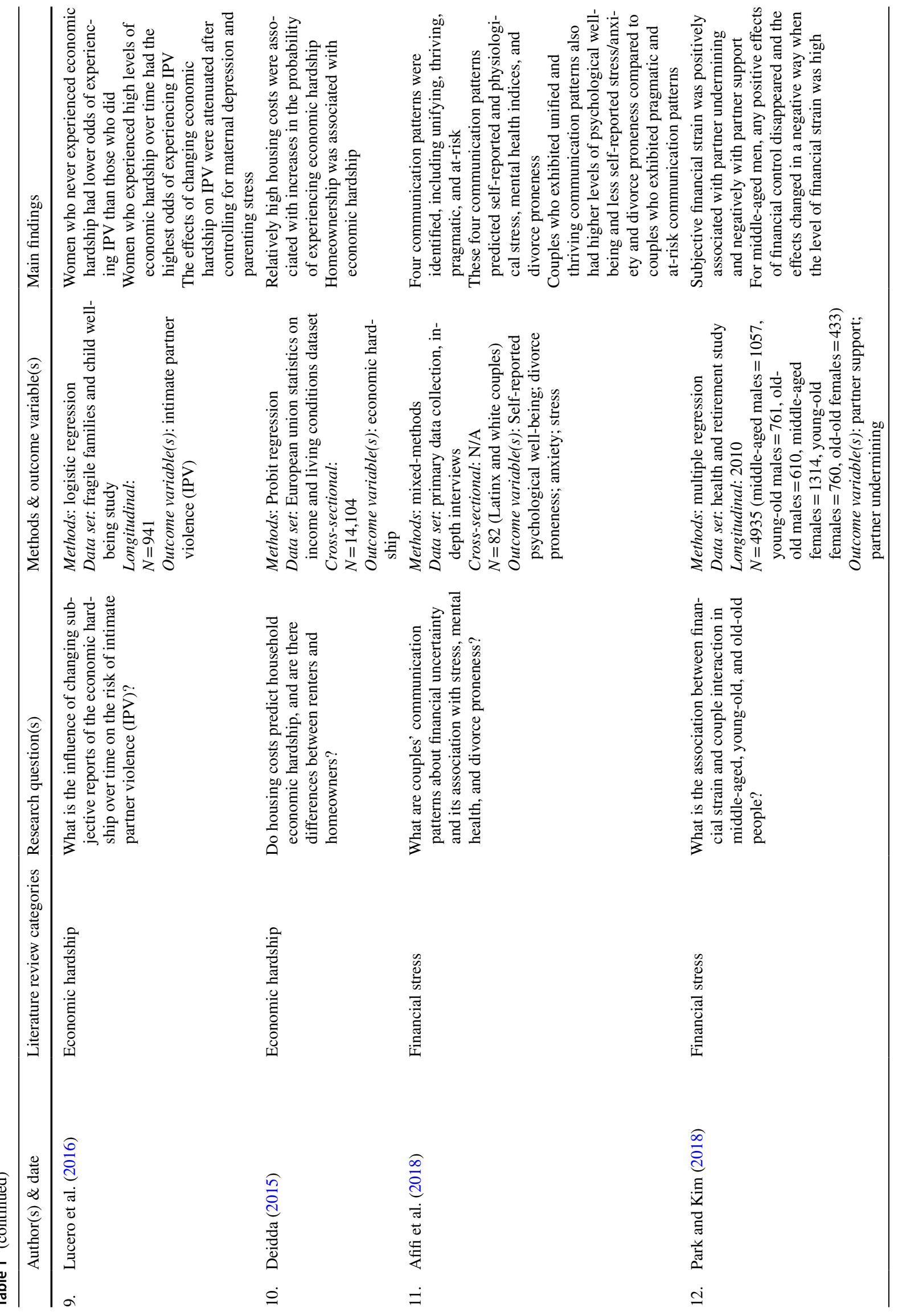




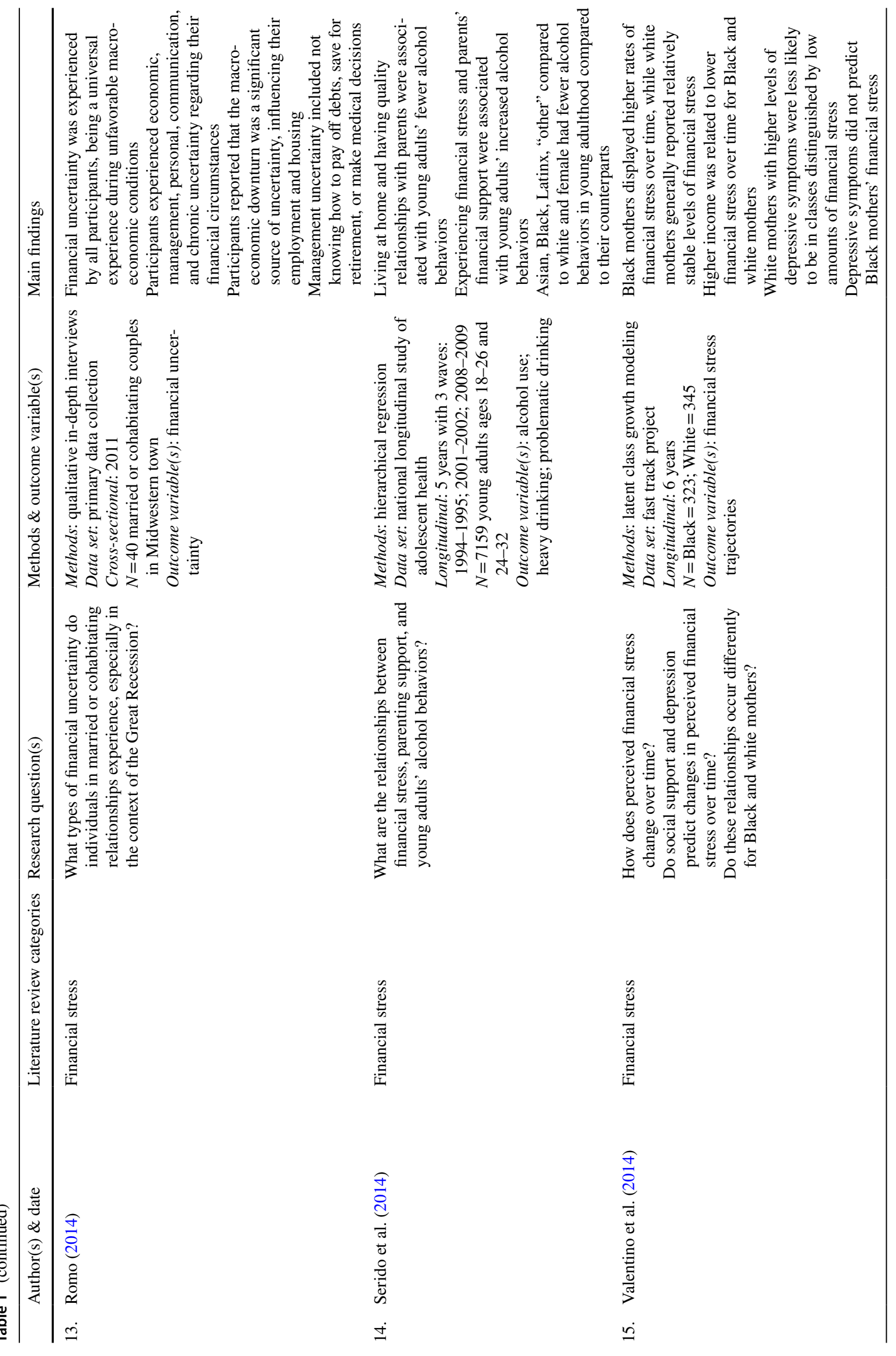




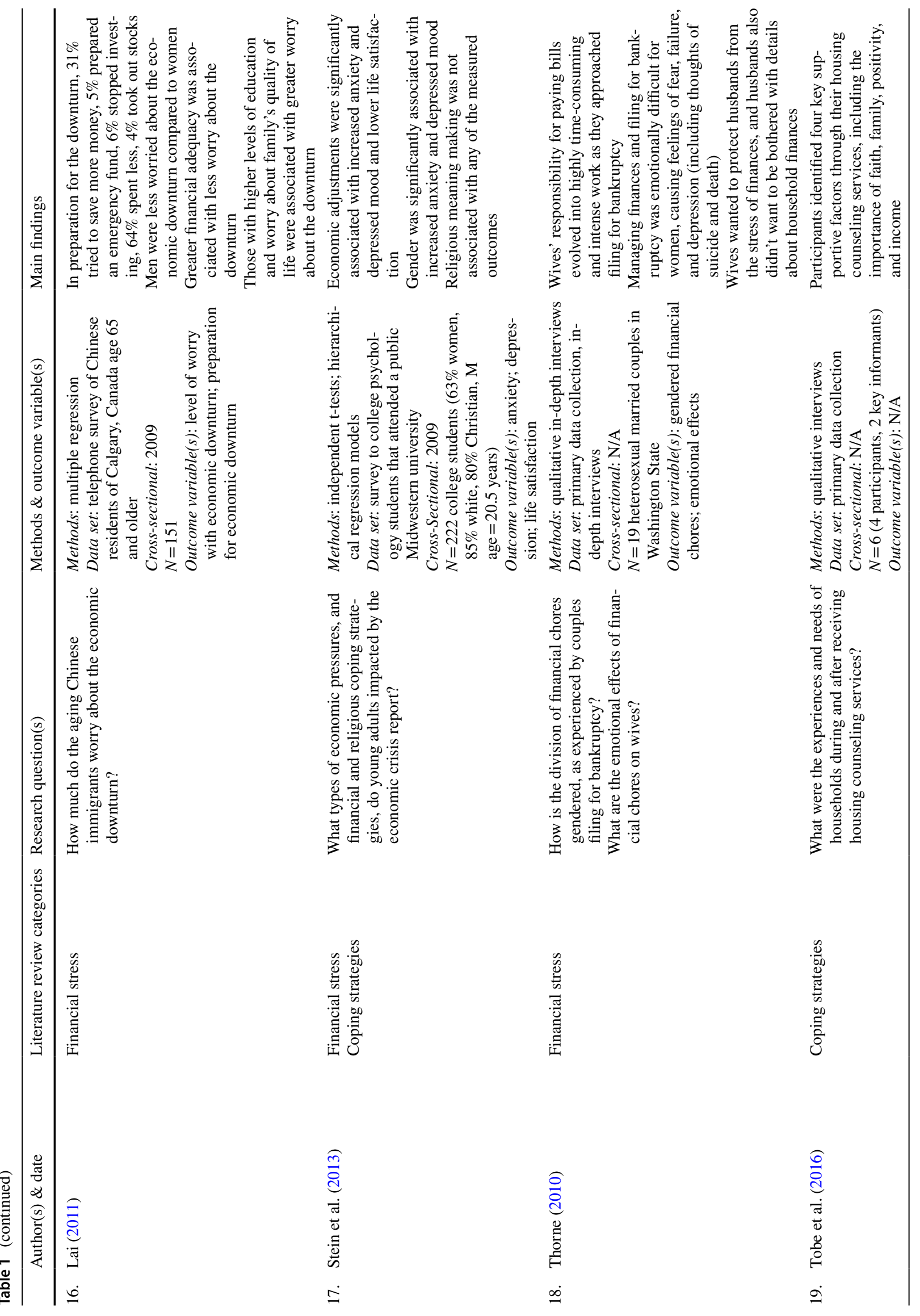




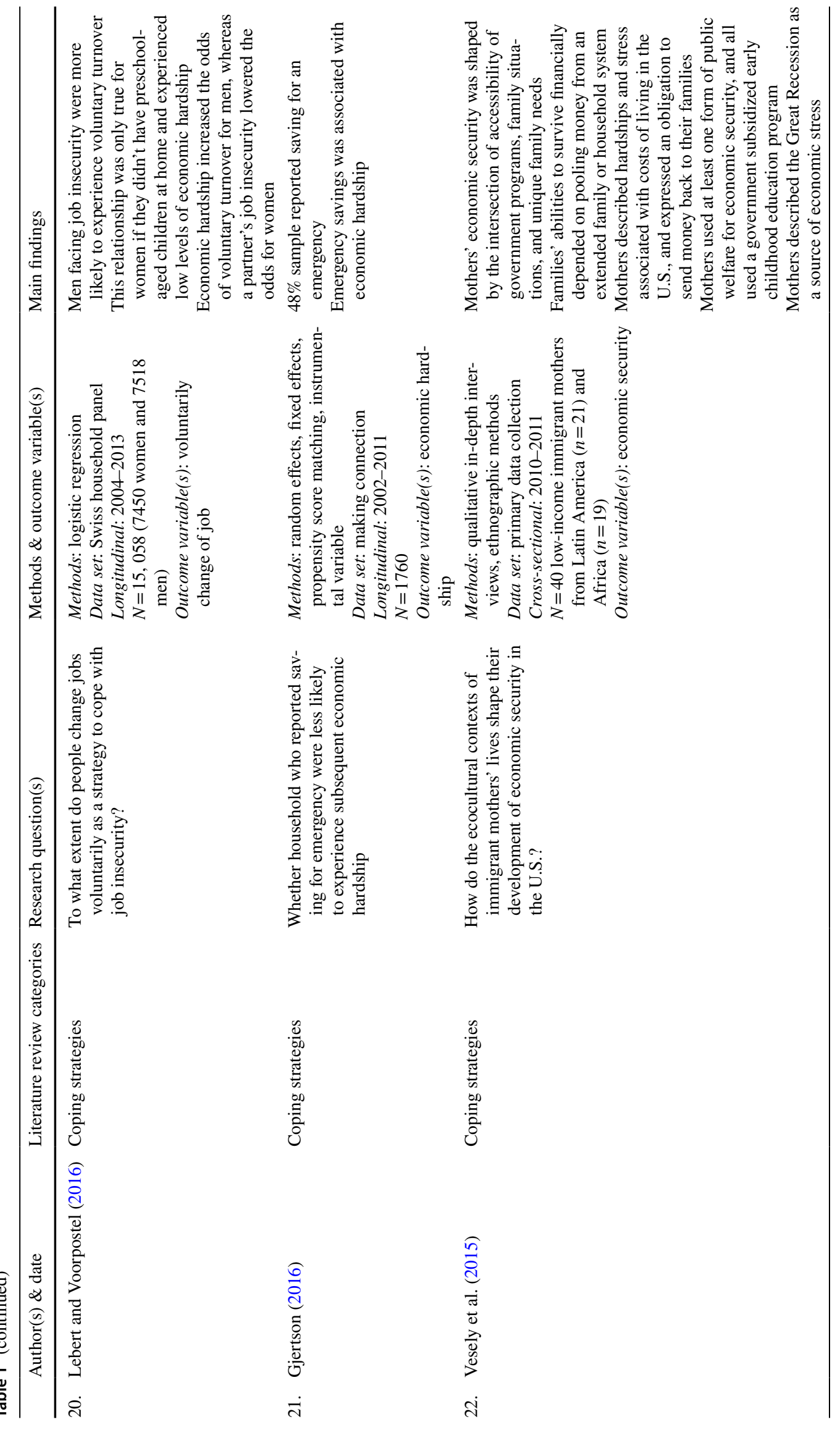




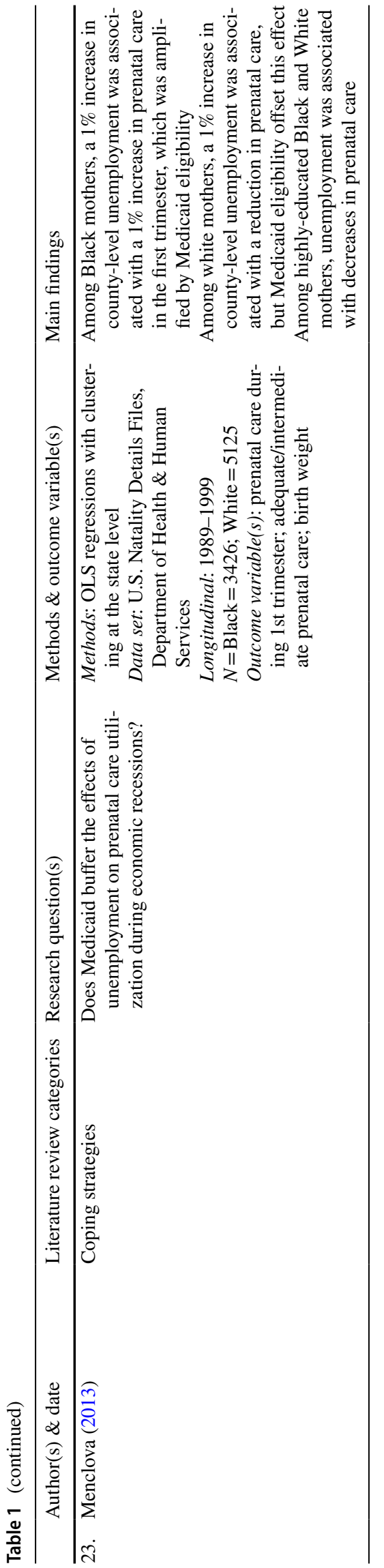

auto title lenders. For example, households with constrained credit were more likely to use payday loans than those who were not (Lee and Kim 2018). In the years following the Great Recession, many households reported that a payday loan was the only option available to them (Lee and Kim 2018).

Families struggled to manage their debt during the economic downturn and turned to public welfare for support (Kim and Wilmarth 2016). Public welfare can help families avoid debt or help them to repay current debts. Kim and Wilmarth (2016) found that $54 \%$ of the households receiving public welfare were able to meet debt-to-income guidelines compared to only $46 \%$ of households who were not receiving assistance, thus showing the government's role in helping households manage their debt especially during an economic downturn. Some families had been accumulating debt when the Great Recession began and were therefore more vulnerable. In their exploration of the determinants of filing for bankruptcy, Bauchet and Evans (2019) found that having higher credit card debt was positively associated with filing for bankruptcy while having higher asset amounts was negatively associated. Moreover, having educational debt from student loans was negatively associated with filing for bankruptcy, potentially highlighting that certain types of debt could have differential effects on the likelihood of filing for bankruptcy.

There were also differences in income, wealth, and debt by race, class, and gender identity (Malone et al. 2010; Rhine et al. 2016; Rauscher and Elliott 2016). For example, compared to White families, Black and Latinx families were less likely to own a savings account and had less access to liquid assets like money market, mutual fund, or retirement accounts (Rhine et al. 2016). Higher income households had more financial resources to buffer them from income and wealth losses compared to lower income households (Rauscher and Elliott 2016). Gender differences in real wages also suggest that the Great Recession affected men's and women's wages differently. Women spent more time on activities like cooking meals and childcare than men (Kuehn 2016). Time spent caring for children was consistently negatively associated with real wages, such that more time spent caring for children resulted in a decrease in actual wages (Kuehn 2016).

\section{Economic Hardship}

Economic hardship, also referred to as material hardship, refers to families' inability to meet their needs such as food, clothing, and health care (Mimura 2008; Rios and Zautra 2011). Closely related to poverty, economic hardship is a multidimensional construct and has been assesssed by a host of measures that go beyond traditional poverty measures that are based primarily on income thresholds. Because the 
construct taps into multiple, distinct dimensions of wellbeing (Iceland and Bauman 2007), economic hardship has been frequently examined in the aftermath of the Great Recession to gain nuanced understandings of families' experiences. Examples of economic hardship reviewed in the literature include food, housing, health care, education, and bankruptcy, which together reflect families' difficulty in meeting their needs (Heflin 2016).

Many Americans experienced abrupt changes in employment, income, and wealth during and after the Great Recession that were associated with their economic hardship (Bauchet and Evans 2019; Deidda 2015; Heflin 2016). For example, Heflin (2016) found that experiencing income losses and having a person with disability join the household were associated with hardships related to housing, health care, and other essential expenses like food. Analyzing data from five European countries, Deidda (2015) found that housing costs were a financial burden and were associated with economic hardship, such as preventing families from spending money on health care, education, food, and clothing. Findings from these studies converge to suggest that many families lived in a time of financial instability and were vulnerable to financial shocks. Changes in life circumstances can easily place households at risk of experiencing economic hardship, ranging from diffculty in covering basic needs to filling for bankruptcy (Bauchet and Evans 2019; Deidda 2015; Helfin 2016).

Economic hardship inevitably places stress on family relationships (Masarik and Conger 2017; McCubbin et al. 1980), which can make some more vulnerable to abuse and violence (Lucero et al. 2016; Showalter 2016). Lucero, Lim, and Santiago (2016) examined the link between economic hardship and intimate partner violence with a sample of 941 women in committed relationships. The longitudinal data analyzed in this study allowed for an examination of economc hardship over a 10-year timespan between 1999 and 2010 that included the Great Recession. Continuously high levels of economic hardship over time elevated the risk of intimate partner violence, implying that ongoing economic hardship can be an additive stressor that subjects women to intimate partner violence.

\section{Financial Stress}

Families experience financial-related psychological stress or distress when they do not have adequate income, wealth, or debt to afford economic hardship (Lai 2011; Park and Kim 2018; Thorne 2010; Sweet et al. 2013). A concept that is related to well-being (CFPB 2015), financial stress arises when families are unable to meet their current and ongoing financial obligations. Financial stress is often operationlized as the physical or mental health symptoms that arise from having difficulty meeting basic needs, difficulty paying bills, and money leftover at the end of the month (Afifi et al. 2018; Ponnet et al. 2016; Romo 2014; Valentino et al. 2014). These indicators that measure the extent to which families lack the financial resources to afford current or persistent obligations help to explain why greater income and wealth are often associated with lower financial stress (Lai 2011; Romo 2014; Valentino et al. 2014).

Financial stress presented differently among individuals within and across families. Women, for example, experienced the effects of financial stress by having poorer physical and mental health when compared to men (Afifi et al. 2018; Lai 2011; Park and Kim 2018; Stein et al. 2013; Thorne 2010). In heterosexual couples, women reported higher levels of stress and anxiety than their partners in anticipation of having conversations about money (Afifi et al. 2018). Women's higher levels of financial stress could have been partly due to the fact that they were responsible for managing their households' finances during economic hardship. Thorne (2010) interviewed couples who were filing for bankruptcy, finding that women were often solely responsible for financial decision-making during this time and that they experienced severe stress. Overwhelmed with the responsibilities of paying taxes and responding to creditors, one woman prayed she would die during an upcoming surgery to escape her financial stress, "I was to the point where when I went in for surgery, I prayed to God that I didn't wake up...I just didn't want to come home...I wanted to have an easy suicide" (Thorne 2010, p. 194).

There were also differences in financial stress across racial groups (Afifi et al. 2018; Park and Kim 2018; Serido et al. 2014; Valentino et al. 2014). For instance, White young adults exhibited higher rates of alcohol use and heavy drinking in the presence of financial stress when compared to their Asian, Black, and Latinx counterparts (Serido et al. 2014). In a study that examined the communication patterns and stress levels of White and Latinx heterosexual couples, Latinx couples often presented as a united front, used humor, and blamed the Great Recession for their economic hardship (Afifi et al. 2018). Couples that adopted these communication patterns also exhibited lower cortisol levels. A study that examined financial stress longitudinally found that Black mothers displayed higher rates of financial stress over time, whereas White mothers' stress was stable yet persistent (Valentino et al. 2014). For White mothers, their stress could be explained in part by their depressive symptoms. However, depressive symptoms did not predict Black mothers' stress (Valentino et al. 2014), which might be better explained by disparities in income, wealth, and debt (Hamilton and Darity 2017; Pfeffer et al. 2013) and could indicate that popular scales validated on White populations are inadequate for measuring Black women's depression (Jones and Ford 2008; Watson and Hunter 2015; Woods-Giscombé and Lobel 2008). 


\section{Coping Strategies}

Families experienced econonic hardship and mounting financial stress in the post Great Recession era. A stream of research has investigated how individuals and families coped with economic hardship and financial stress, especially focusing on certain demographic groups or social identities such as low-income households (Bauchet and Evans 2019; Gjertson 2016; Kim and Wilmarth 2016; Tobe et al. 2016), immigrants (Vesley et al. 2015), women (Menclova 2013), and young adults (Stein et al. 2013). The coping strategies that individuals and families adopted varied to a great extent, with some similarities.

Faith and religious beliefs were a commonly investigated and discussed coping strategy. For example, Tobe et al. (2016) observed families receiving counseling services and found that they used faith to build support systems through new relationships with others. Similarly, Stein et al. (2013) described how college students used religious coping strategies to make sense of the economic crisis and loss. College students that responded to surveys perceived the economic crisis as a punishment from God; although their religious perceptions did not appear to be associated with self-reported well-being (Stein et al. 2013). Reliance on family and relationships were observed among economically distressed families: Strong family relationships helped to sustain those under emotional and financial stress among Midwest families (Tobe et al. 2016) and immigrant mothers (Vesely et al. 2015).

Families also coped financially by borrowing from payday loans, filing for bankrutpcy, using government susidies, changing jobs, or saving for emergencies (Gjertson 2016; Lebert and Voorpostel 2016), espeically among low-income families (Kim and Wilmarth 2016) and families with credit constraints (Bauchet and Evans 2019; Lee and Kim 2018, Tobe et al. 2016). These coping strategies align with the literature on economic hardship, which concludes that many families remained financially stressed during the illusory economic recovery. Notably, these coping strategies were closely linked to the recession. Specifically, the likelihoods of using payday loans and filing bankrupcy were higher among families with damaged credit and credit card debt (Bauchet and Evans 2019; Lee and Kim 2018, Tobe et al. 2016). Studies imply that the magnitudes of these associations increased strongly following the Great Recession. In addition, race and life circumstances seemed to matter when it came to using these strategies. For instance, given the constraints created by discrimination and inequality (Shapiro 2017), Black respondents and households with a dependent child had higher likelihoods of using payday loans (Lee and Kim 2018). Having a new child enter the family was associated with an increased possiblity of filling for bankrupcy, while retiring was associated with a decreased possiblity of filing for bankruptcy (Bauchet and Evans 2019).

Public welfare was an important strategy for families who utilized these government-sponsored programs to cope with economic hardship and financial stress. Studies suggest that public welfare helped families to manage their debt (Kim and Wilmarth 2016), as well as to improve their physical health outcomes (Menclova 2013). These findings are especially relevant given that participants included low-income families (Kim and Wilmarth 2016) and women (Menclova 2013), who were disproportionately impacted by the Great Recession (Baker et al. 2019; Pfeffer et al. 2013). For families that used public welfare, these government programs were just one component of a series of supports that they cobbled together to cope with econimc hardship and financial stress (Vesely et al. 2015; Tobe et al. 2016), suggesting that public welfare in and of itself was far from sufficient (Edin and Shaefer 2016).

\section{The Invisible Hand(s) of Financial Stress}

The current focus of JFEI's published literature aligns with a neoliberal perspective of financial stress, which locates the responsibility for experiencing financial stress with individuals and families as opposed to the economy and economic environments (Abernathy et al. 2019; Lin and Neely 2020). The market forces of neoliberal capitalism are rendered invisible. This perspective deemphasizes or ignores macroeconomic trends from a capitalist system that raises the stakes on individuals and families and contributes to their financial stress, such as reduced collective bargaining power (Jacobs and Myers 2014; Western and Rosenfeld 2011) and low and stagnant wages in the labor market (Mishel et al. 2012); widening income and wealth inequality (Kim and Sakamoto 2008; Piketty 2014); subprime financial products promoted by banks and lenders (Baradaran 2017); gentrification and rising housing costs (Maharawal 2017; Moore 2009); and environmental hazards like air pollution and lead-tainted water (Benz 2019; Mohai et al. 2009; Pulido 2016). Moreover, given that the published literature often attempts to understand differences in financial stress by race, class, and gender, a lack of consideration to the economy and economic environments may unwittingly advance harmful stereotypes by placing blame on families for their lived experiences with systemic racism, classism, and sexism (Hamilton and Darity 2017; Walsdorf et al. 2020).

The Great Recession-as the COVID-19 Pandemic Recession will become-is a critical backdrop in the literature on economic hardship, income, wealth, and debt, financial stress, and coping strategies. Recognizing the importance of the economy and families' economic environments, most authors of the articles we reviewed justified their 
current data and analyses in reference to the Great Recession and situated their findings within this context (Bauchet and Evans 2019; Thorne 2010; Vesely et al. 2015). Though, despite this contextualization, authors often explained families' financial circumstances by using language like choices, preferences, values, and information. This language situates explanations within the individual or family, while deemphasizing the economy and economic environments.

There are numerous examples of the literature's deemphasis of the economy and economic environments in favor of adopting individualized explanations. For instance, Kim and Wilmarth (2016) examined the relationship between receiving public welfare and households' debtto-income ratios. By exploring public welfare, Kim and Wilmarth (2016) explored the potential role of government in supporting families who were experiencing economic hardship. An acknowledgment of government's role aligns with the perspective that the welfare state adjusts for the failures of capitalism (Azmanova 2012). However, in discussing possible interventions, the authors concluded that financial educators, counselors, and coaches could also assist families in managing their debt, writing, "Promoting better financial management for households could assist in saving resources from the government" (Kim and Wilmarth 2016, p. 357). In other words, individualized interventions like financial education or coaching may assist families in responding to macroeconomic contexts that prevent them from meeting their current and ongoing financial obligations. In another example, Rhine and colleagues (2016) examined whether savings account ownership was associated with preventing wealth losses during the Great Recession, writing “...families recognized the value of possessing a savings account even as wealth or income may have declined to some degree" ( $p$. 345). The authors inferred that there was an individualized, value-based explanation for rates of savings account ownership and or wealth during the Great Recession, despite reporting on disparities by household income and race that were evidence of classism and racism (Rhine et al. 2016). In a similar exploration of savings account ownership among young people, Friedline et al. (2014) wrote: "The wealth and resources of [their] households likely help them establish their savings accounts as children" (p. 406). While employing an explanation that hints at the ways the economy and policies enable intergenerational wealth transmissions, the passive language used by Friedline et al. (2014) discounts the centrality of this capitalist system.

There are some examples of how the reviewed literature emphasizes the importance of the economy and economic environments. For example, Lai (2011), Thorne (2010), and Vesely et al. (2015) wrote explicitly about the economy in which families were situated. In exploring the experiences of older Chinese immigrants in Canada during the economic downturn, Lai (2011) wrote: "Challenges related to institutional racism, mistrust of the system, inadequate knowledge of services available...The recession can further contribute to the discrimination against older people, particularly those who come closer to the retirement age in the work force" (p. 521, 522). By first identifying institutional racism and discrimination, Lai (2011) recognized macroeconomic explanations for older Chinese immigrants' experiences while acknowledging the existence of individual explanations like knowledge of available services. Vesely et al. (2015) interviewed low-income immigrant mothers who moved to the US from Latin America and Africa, writing, "...ecocultural theorists account for the ecological factors, including 'institutional forces' that impact families' daily lives, and in turn, individuals' wellbeing" (p. 515). Vesely et al. identified "institutional forces" to emphasize the importance of the economy and families' economic environments for understanding their well-being.

\section{Toward an Emphasis on the Economy and Economic Environments}

Families are situated within specific historic, cultural, social, political, and economic contexts. An emphasis on the economy and economic environments illuminates or makes visible some of these contexts and policy decisions that are responsible for families' well-being, which is especially important in the wake of the Great Recession and COVID-19 Pandemic Recession. While explanations rooted in individuals and families-such as focusing on a family's budgeting or observing their levels of financial knowledge-can decontextualize and flatten families' experiences, an added emphasis on the economy and economic environments offers more holistic and accurate understandings.

\section{The Economy of Capitalism}

Families' financial stress and well-being are influenced by the economy and associated policy decisions (Baradaran 2017; Mian and Sufi 2014) — the national and increasingly global macroeconomic sites of labor and production, trade, and consumption of goods and services. For example, policy decisions to reduce workers' collective bargaining power altered how labor for production was compensated and contributed to declines in union membership, decreased wages, and rising inequality (Western and Rosenfeld 2011). Over time, families experienced these policy decisions as declines in their income that occurred simultaneously with the rising costs of goods and services, compelling them to borrow debt to cope financially (Federal Reserve Bank of New York 2019). Therefore, the economy and related policy decisions are key drivers and explanations of families' financial stress and well-being. 
The United States' economy is capitalist, and policy decisions are made in relation to capitalism. In its simplest definition, capitalism is an economic system where the means of production are privately owned (Hahne and Wright 2016; Wright 2018). That is, individuals do not realize the profits produced from their own labor; rather, private companies keep these profits in exchange for paying modest wages. Moreover, the current version of capitalism emphasizes individualism or personal responsibility and relies on finance for economic growth. Capitalism's neoliberal paradigm emerged in the 1970s to emphasize individualism or personal responsibility, and has been characterized by limited state public welfare provision, privatization, deregulation, and free market competition (Abernathy et al. 2019). Neoliberalism's related policy decisions have intensified financial pressures on families vis-à-vis the state's withdrawal. Capitalism also requires the pursuit of income and profits for economic expansion (Friedman 1962; Romer 2014), which is increasingly driven by finance where income and profits are generated through financial channels instead of through labor and production (Lin and Neely 2020).

Capitalism pursues and creates profits by assigning difference, using social constructions that confer hierarchies of desirability or worthiness onto traits and characteristics for stratifying economic value (Cottom 2017; Robinson 1983). Capitalism's differential economic valuations are discriminatory, enabling and even requiring people or property to be valued differently based on their proximity to social constructions of whiteness, maleness, and other privileged identities (Garrett-Scott 2019; Robinson 1983; Wang 2018). Many scholars criticize capitalism as a racialized and gendered project (Garrett-Scott 2019; Wang 2018). For example, the use of credit scoring assigns differential economic value to individuals based on a range of factors like borrowing debt and paying bills, and influences how banks make lending decisions (Lauer 2017; Nopper 2019). Credit scoring models assign higher values to Whites while assigning lower values to Black and Brown peoples that limit their lending options and contribute to their higher likelihoods of using payday loans (Lee and Kim 2018). Differential economic value enables a house to be valued more highly when it is located near desirable amenities like a park or central business district, or near socially-constructed desirable traits like communities with wealthier and whiter populations (Rothstein 2017; Taylor 2019), which has implications for access to credit and net worth accumulation. Therefore, a critical analysis of capitalism is important for understanding families' financial stress and well-being, particularly for identifying evidence of discrimination in observed the differences by race, class, and gender (Afifi et al. 2018; Park and Kim 2018; Thorne 2010; Lai 2011; Vesely et al. 2015).

\section{Economic Environments}

In addition to the broader macro economy, families are situated within local and regional economic contexts. These economic environments-and the resources and opportunities available within - influence families' financial stress and well-being. Decades of research in sociology (Sharkey et al. 2017; Small and McDermott 2006), social work (Green and McDermott 2010; Kang et al. 2019; Trattner 1999), geography (Galster et al. 2016; Hedman et al. 2015; Pike and Pollard 2015), and public health (Dankwa-Mullan and PérezSTable 2016; Pérez and Martinez 2008; Shore et al. 2015) have emphasized the importance of families' environments for understanding various aspects of well-being.

Financial services are one type of resource or opportunity within economic environments that may influence families' financial stress and well-being. Mounting evidence confirms the importance of financial services within local economic environments. For instance, the presence, absence, or relative mix of financial services provide various resources and opportunities for families to supplement income, access credit, accumulate wealth, and cope with economic hardship. Individuals who live or grew up in communities with at least some bank branches are more likely to use these services, have bank accounts (Celerier and Matray 2017; Goodstein and Rhine 2017), and have higher credit scores (Brown et al. 2016). Moreover, the presence and concentration of higher-cost, lower quality financial services like payday lenders in economic environments undermine families' financial stress and well-being. The concentration of higher-cost, lower quality financial services is associated with increased use of these services, and their use is associated with having lower credit scores and struggling to pay bills (Bhutta 2014; Melzer 2011).

One reason that a focus on economic environments is so important is because resources and opportunities are highly variable from one community to the next. Racism and classism have created stark geographies of segregation (Faber 2018; Rothstein 2017), meaning that there are vast differences in families' economic environments that can explain differences in their financial stress and well-being. Policy decisions like those that created redlining, for example, codified racial and economic segregation into the geographic landscape. Redlining refers to a set of intentionally created and mutually reinforcing policies and practices implemented by banks, lenders, real estate agents, and government that excluded Black and Brown borrowers from the mortgage lending market (Rothstein 2017). The Home Owners Loan Corporation's (HOLC) residential security maps assigned differential economic value to communities, where communities "greenlined" were predominantly White while communities "redlined" as hazardous for were predominantly Black and Brown (Baradaran 2017; Rothstein 2017). Since 
banks and lenders would not originate new loans in redlined communities, Black and Brown borrowers were excluded from the mortgage market and from the benefits of wealth via home equity (George et al. 2019).

Segregation shapes the resources and opportunities within local economic environments (Faber 2019; Rothstein 2017). For example, higher-cost, lower quality financial services like payday lenders and check cashers tend to concentrate in Black and Brown communities that are avoided by banks and credit unions (Baradaran 2015; Celerier and Matray 2017; Faber 2018, 2019; Jorgensen and Akee 2017). Even the availability and use of digital technologies are subject to spatially organized segregation. Increases in communities' Black and Brown populations are associated with decreases in high-speed internet access, online banking, and mobile banking; though, the relationships are opposite for increases in communities' white population (Author). Whether families can apply for a low-cost loan at a bank or manage their money online depends to some extent on how segregation determines the resources and opportunities within their communities.

\section{Future Directions and Conclusions}

The literature on families' financial stress and well-being can be expanded upon and advanced by focusing on the economy and economic environments. We offer three possibilities for future directions, including applying or developing theories, measuring variables and incorporating them into models, and analyzing policy decisions. These future directions are especially important for research that attempts to understand differences by race (Faber 2018), class (Pfeffer et al. 2013), and gender (Baker et al. 2019).

Future research should develop or apply theories that incorporate the economy and or economic environments into explanations of families' financial stress and well-being. The existing literature relies on family stress theory, life cycle theory, and ecocultural theory (Kim et al. 2016; Masarik and Conger 2017; Tobe et al. 2016). While ecocultural theory accounts for economic environments (Vesely et al. 2015), neither life cycle theory nor family stress theory were designed to take the economy or economic environments into consideration. By failing to apply theories that incorporate these explanations, research instead focuses on individual-level solutions to larger social and economic problems. For instance, the evolution of the stress paradigm shows that a focus on stressful life events can obscure the role of larger social and economic factors on physical health and well-being (Link and Phelan 1995). Theories such as ecological systems theory (Bronfenbrenner 1975) can account for the interaction between an individual and their environment. Ecological systems theory posits that an individual's environment comprises multiple systems, including a macrosystem characterized by rules, laws, and unwritten norms (Bronfenbrenner 1979). The economy and an individual's economic environment are part of this larger macrosystem. Therefore, a focus on theories that do not consider the economy and economic environments can obscure the role they have in explaining families' financial stress and well-being.

Research can also measure and test macro economic and environmental variables as explanations of families' financial stress and well-being. The existing literature published in JFEI rarely measures macro economic or environmental variables, despite describing the importance of these contextual factors. The ramifications of the Great Recession such as income and wealth losses, home foreclosures, and rising debt have been widely experienced and contributed to a multitude of families' economic hardships and financial stress (Mian and Sufi 2014). Nevertheless, the literature keeps the macro economy in the background or simply discusses these factors as missing variables (Heflin 2016). The absence of variables measuring the economy and economic environments is a critical gap and presents an opportunity for future research. Future research can measure and test variables on the economy and economic environments to more fully understand financial stress and well-being. Examples of such variables include job losses, housing costs, home foreclosure rates, loan originations, and access to financial services.

Future research should also test the effects of policy decisions on families' financial stress and well-being, such as the policy decisions that codified redlining (Rothstein 2017), enable payday lending (Bhutta 2014), precipitate home foreclosure (Bauchet and Evans 2019, or implement public welfare programs (Kim and Wilmarth 2016, Menclova 2013). While extant studies examine home foreclosure and debt (Bauchet and Evans 2019; Kim and Wilmarth 2016), they fail to test the effects of policy decisions on financial stress and well-being outcomes. Similarly, policies regulating payday lending can have widespread impacts on families' financial stress and well-being (Melzer 2011). However, few studies within the JFEI literature have investigated how payday lending regulations affect financial stress and wellbeing - even as these lenders expanded during and after the Great Recession (Faber 2018). Similarly, as public welfare programs appear to help families cope with economic hardship (Kim and Wilmarth 2016; Menclova 2013), research should examine how variations in public welfare policy implementation impact financial stress and well-being. Longitudinal studies are usefiul here given that a longitudinal framework is often needed to examine changes in the economy and in policy decisions over time. Future research should address this knowledge gap by testing the impacts of relevant policy decisions.

Lastly, racism, classism, and sexism at systemic levels mean that families experience economic downturns 
differently. As evidence of disparate impacts (if not discrimination) during the Great Recession, subprime lenders targeted Black and Brown communities for lower-quality, higher-cost loans (Faber 2018; Hamilton and Darity 2017) and women accumulated significant amounts of debt to support their families (Baker et al. 2019). Racial and economic segregation may further force the concentration of these differential experiences. Any future research that attempts to explain differences in families' financial stress and well-being by race, class, or gender must take into account systemic explanations, like forms of discrimantion and the economy and economic environments. A failure to develop or apply theories, measure variables, or test policy decisions-even while describing these differences-risks blaming families for the discrimination and marginalization that they experience.

In conclusion, this paper fills gaps in the existing JFEI literature on families' financial stress and well-being by emphasizing the importance of the economy and economic environments. A focus on the economy and economic environments has always been important. However, now, this focus is especially necessary for understanding the immediate and prolonged impacts of the COVID-19 Pandemic Recession given the absence of public welfare and skyrocketing unemployment and debt. Future research must not ignore the contexts and policy decisions with regard to the COVID-19 Pandemic Recession that contribute to families' stress and well-being. We therefore encourage researchers to incorporate and or investigate explanations of families' financial stress and well-being that are rooted in the economy and economic environments.

Funding No funding was received for this literature review article.

\section{Compliance with Ethical Standards}

Conflict of interest The authors have no conflict of interest to report for this literature review article.

Ethical Approval No animals were involved in this literature review article. This literature review article does not contain any studies with human participants performed by any of the authors.

Informed Consent Informed consent was not applicable for this literature review article.

\section{References}

Abernathy, N., Hamilton, D., \& Morgan, J. M. (2019). New rules for the 21st century: Corporate power, public power, and the future of the American economy. New York: Roosevelt Institute. Retrieved May 7, 2019, from https://rooseveltinstitute.org/
wp-content/uploads/2019/04/Roosevelt-Institute_2021-Repor t_Digital-copy.pdf

Addo, F., Houle, J., \& Sassler, S. (2019). The changing nature of the association between student loan debt and marital behavior in young adulthood. Journal of Family and Economic Issues, 40(1), 86-101. https://doi.org/10.1007/s10834-018-9591-6.

Afifi, T. D., Davis, S., Merrill, A. F., Coveleski, S., Denes, A., \& Shahnazi, A. F. (2018). Couples' communication about financial uncertainty following the Great Recession and its association with stress, mental health and divorce proneness. Journal of Family and Economic Issues, 39(2), 205-219. https://doi. org/10.1007/s10834-017-9560-5.

Azmanova, A. (2012). Social justice and varieties of capitalism: An immanent critique. New Political Economy, 4, 445-463. https:// doi.org/10.1080/13563467.2011.606902.

Baker, A. C., West, S., \& Wood, A. (2019). Asset depletion, chronic financial stress, and mortgage trouble among older female homeowners. The Gerontologist, 59(2), 230-241. https://doi. org/10.1093/geront/gnx137.

Baradaran, M. (2015). How the other half banks: Exclusion, exploitation, and the threat to democracy. Cambridge, MA: Harvard University Press.

Baradaran, M. (2017). The color of money: Black banks and the racial wealth gap. Cambridge, MA: Harvard University Press.

Bauchet, J., \& Evans, D. (2019). Personal bankruptcy determinants among U.S. households during the peak of the Great Recession. Journal of Family and Economic Issues, 40(4), 577-591. https ://doi.org/10.1007/s10834-019-09627-1.

Benz, T. (2019). Toxic cities: Neoliberalism and environmental racism in Flint and Detroit Michigan. Critical Sociology, 45(1), 49-62. https://doi.org/10.1177/0896920517708339.

Bhutta, N. (2014). Payday loans and consumer financial health. Journal of Banking \& Finance, 47, 230-242. https://doi.org/10.1016/j. jbankfin.2014.04.024.

Bronfenbrenner, U. (1975). Reality and research in the ecology of human development. Proceedings of the American Philosophical Society, 119(6), 439-469.

Bronfenbrenner, U. (1979). Contexts of child rearing: Problems and prospects. American Psychologist, 34(10), 844-850. https://doi. org/10.1037/0003-066X.34.10.844.

Brown, J., Cookson, A., \& Heimer, R. (2016). Growing up without finance. Miami, FL: 7th Miami Behavioral Finance Conference, Conference Proceedings. https://ssrn.com/abstract=2809164.

Celerier, C., \& Matray, A. (2017). Bank branch supply and the unbanked phenomenon. Zurich, Switzerland: University of Zurich. Retrieved June 17, 2019, from https://www8.gsb.colum bia.edu/faculty-research/sites/faculty-research/files/finance/Finan ce\%2520Seminar/Fall\%25202016/Unbanked_October2016.pdf

Consumer Financial Protection Bureau. (2015). Financial well-being: The goal of financial education. Washington, DC: CFPB. Retrieved April 16, 2019, from https://files.consumerfinance .gov/f/201501_cfpb_report_financial-well-being.pdf

Cottom, T. M. (2017). Lower-ed: The troubling rise of for-profit colleges in the new economy. New York, NY: The New Press.

Dankwa-Mullan, I., \& Pérez-Stable, E. (2016). Addressing health disparities is a place-based issue. American Journal of Public Health, 106(4), 637-639. https://doi.org/10.2105/ AJPH.2016.303077.

Deidda, M. (2015). Economic hardship, housing cost burden and tenure status: Evidence from EU-SILC. Journal of Family and Economic Issues, 36(4), 531-556. https://doi.org/10.1007/s1083 4-014-9431-2.

Edin, K., \& Shaefer, L. (2016). \$2.00 a day: Living on almost nothing in America. New York: Houghton Mifflin Harcourt.

Faber, J. W. (2018). Cashing in on distress: The expansion of fringe financial institutions during the Great Recession. Urban Affairs 
Review, 54(4), 663-696. https://doi.org/10.1177/1078087416 684037.

Faber, J. W. (2019). Segregation and the cost of money: Race, poverty, and the prevalence of alternative financial institutions. Social Forces, 98(2), 819-848. https://doi.org/10.1093/sf/ soy 129 .

Fan, L., \& Chatterjee, S. (2019). Financial socialization, financial education, and student loan debt. Journal of Family and Economic Issues, 40, 74-85. https://doi.org/10.1007/s10834-018-9589-0.

Federal Reserve Bank of New York. (2019). Quarterly report on household debt and credit: 2019 Q3. New York: Federal Reserve Bank of New York, Research and Statistics Group. Retrieved December 1, 2019, from https://www.newyorkfed.org/medialibrary/inter actives/householdcredit/data/pdf/HHDC_2019Q3.pdf

Fisher, P., \& Montalto, C. (2011). Loss aversion and saving behavior: Evidence from the 2007 U.S. survey of consumer finances. Journal of Family and Economic Issues, 32, 4-14. https://doi. org/10.1007/s10834-010-9196-1.

Fontes, A. (2011). Differences in the likelihood of ownership of retirement saving assets by the foreign and native-born. Journal of Family and Economic Issues, 32, 612-624. https://doi. org/10.1007/s10834-011-9262-3.

Friedline, T., Nam, I., \& Loke, V. (2014). Households' net worth accumulation patterns and young adults' financial health: Ripple effects of the Great Recession? Journal of Family and Economic Issues, 35(3), 390-410. https://doi.org/10.1007/s1083 4-013-9379-7.

Friedman, M. (1962). Capitalism and freedom: Fortieth anniversary edition. Chicago: University of Chicago Press.

Galster, G., Santiago, A., Lucero, J., \& Cutsinger, J. (2016). Adolescent neighborhood context and young adult economic outcomes for low-income African Americans and Latinos. Journal of Economic Geography, 16(2), 471-503. https://doi.org/10.1093/jeg/ lbv004.

Garrett-Scott, S. (2019). Banking on freedom: Black women in U.S. finance before the new deal. New York: Columbia University Press.

George, S., Hendley, A., Macnamara, J., Perez, J., \& Vaca-Loyola, A. (2019). The plunder of Black wealth in Chicago: New findings on the lasting toll of predatory housing contracts. Durham, NC: Duke University, The Samuel DuBois Cook Center on Social Equity. Retrieved June 1, 2019, from https://socialequity.duke. edu/wp-content/uploads/2019/10/Plunder-of-Black-Wealth-inChicago.pdf.

Gjertson, L. (2016). Emergency saving and household hardship. Journal of Family and Economic Issues, 37(1), 1-17. https://doi. org/10.1007/s10834-014-9434-z.

Goodstein, R., \& Rhine, S. (2017). The effects of bank and nonbank provider locations on household use of financial transaction services. Journal of Banking and Finance, 78, 91-107.

Green, D., \& McDermott, F. (2010). Social work from inside and between complex systems: Perspectives on person-in-environment for today's social work. The British Journal of Social Work, 40(8), 2414-2430. https://doi.org/10.1093/bjsw/bcq056.

Hahne, R., \& Wright, E. O. (2016). Alternatives to capitalism: Proposals for a democratic economy. Brooklyn, NY: Verso.

Hamilton, D., \& Darity, W. (2017). The political economy of education, financial literacy, and the racial wealth gap. The Federal Reserve Bank of St. Louis Review, 99(1), 59-76.

Hancock, A., Jorgensen, B., \& Swanson, M. (2013). College students and credit card use: The role of parents, work experience, financial knowledge, and credit card attitudes. Journal of Family and Economic Issues, 34, 369-381. https://doi.org/10.1007/s 1083 4-012-9338-8.

Haron, S., Sharpe, D., Abdel-Ghany, M., \& Masud, J. (2013). Moving up the savings hierarchy: Examining savings motives of older
Malay Muslim. Journal of Family and Economic Issues, 34, 314-328. https://doi.org/10.1007/s10834-012-9333-0.

Hedman, L., Manley, D., van Ham, M., \& Östh, J. (2015). Cumulative exposure to disadvantage and the intergenerational transmission of neighborhood effects. Journal of Economic Geography, 15(1), 195-215. https://doi.org/10.1093/jeg/lbt042.

Heflin, C. (2016). Family instability and material hardship: Results from the 2008 survey of income and program participation. Journal of Family and Economic Issues, 37(3), 359-372. https://doi. org/10.1007/s10834-016-9503-6.

Iceland, J., \& Bauman, K. J. (2007). Income poverty and material hardship: How strong is the association? The Journal of SocioEconomics, 36(3), 376-396. https://doi.org/10.1016/j.socec .2006.12.003.

Jacobs, D., \& Myers, L. (2014). Union strength, neoliberalism, and inequality: Contingent political analyses of U.S income differences since 1950. American Sociological Review, 79(4), 752-774. https ://doi.org/10.1177/0003122414536392.

Jones, L., \& Ford, B. (2008). Depression in African American women: Application of a psychosocial competence practice framework. Affilia, 23(2), 134-143. https://doi.org/10.1177/0886109908 314324.

Jorgensen, M., \& Akee, R. (2017). Access to capital and credit in Native communities: A data review, digital version. Tucson, AZ: Native Nations Institute. Retrieved January 3, 2018, from https://nni.arizona.edu/application/files/6514/8642/4513/Acces sing_Capital_and_Credit_in_Native_Communities__A_Data_ Review.pdf.

Kang, J., Fabbre, V., \& Ekenga, C. (2019). "Let's talk about the real issue": Localized perceptions of environment and implications for ecosocial work practice. Journal of Community Practice, 27(3-4), 317-333. https://doi.org/10.1080/10705422.2019.16572 18.

Kim, C. H., \& Sakamoto, A. (2008). The rise of intra-occupational wage inequality in the United States, 1983 to 2002. American Sociological Review, 73(1), 129-157. https://doi. org/10.1177/000312240807300107.

Kim, K. T., \& Wilmarth, M. J. (2016). Government subsidies and household debt burden after the Great Recession. Journal of Family and Economic Issues, 37(3), 349-358. https://doi. org/10.1007/s10834-016-9492-5.

Kramer, K., Andrade, F. C. D., Greenlee, A., Mendenhall, R., Bellisle, D., \& Blanks, R. L. (2019). Periodic Earned Income Tax Credit (EITC) payment, financial stress, and wellbeing: A longitudinal study. Journal of Family and Economic Issues, 40, 511-523. https://doi.org/10.1007/s10834-019-09618-2.

Kuehn, D. (2016). Home production, house values, and the Great Recession. Journal of Family and Economic Issues, 37(1), 99-114. https://doi.org/10.1007/s10834-015-9438-3.

Lai, D. W. (2011). Perceived impact of economic downturn on worry experienced by elderly Chinese immigrants in Canada. Journal of Family and Economic Issues, 32(3), 521-531. https://doi. org/10.1007/s10834-010-9239-7.

Lauer, J. (2017). Creditworthy: A history of consumer surveillance and financial identity in America. New York: Columbia University Press.

Lebert, F., \& Voorpostel, M. (2016). Turnover as a strategy to escape job insecurity: The role of family determinants in dual-earner couples. Journal of Family and Economic Issues, 37(3), 407421. https://doi.org/10.1007/s10834-016-9498-z.

Lee, J., \& Kim, K. T. (2018). The increase in payday loans and damaged credit after the Great Recession. Journal of Family and Economic Issues, 39(2), 360-369. https://doi.org/10.1007/s1083 4-017-9557-0.

Lin, K.-H., \& Neely, M. T. (2020). Divested: Inequality in the age of finance. New York: Oxford University Press. 
Link, B., \& Phelan, J. (1995). Social conditions as fundamental causes of disease. Journal of Health and Social Behavior, 80-94. https://www.jstor.org/stable/2626958

Lucero, J., Lim, S., \& Santiago, A. M. (2016). Changes in economic hardship and intimate partner violence: A family stress framework. Journal of Family and Economic Issues, 37, 395-406. https://doi.org/10.1007/s10834-016-9488-1.

Maharawal, M. (2017). Black Lives Matter, gentrification and the security state in San Francisco Bay Area. Anthropological Theory, 17(3), 338-364. https://doi.org/10.1177/1463499617 732501.

Malone, K., Stewart, S. D., Wilson, J., \& Korsching, P. F. (2010). Perceptions of financial well-being among American women in diverse families. Journal of Family and Economic Issues, 31, 63-81.

Masarik, A. S., \& Conger, R. D. (2017). Stress and child development: A review of the family stress model. Current Opinion in Psychology, 13, 85-90. https://doi.org/10.1016/j.copsyc.2016.05.008.

McCubbin, H. I., Joy, C. B., Cauble, A. E., Comeau, J. K., Patterson, J. M., \& Needle, R. H. (1980). Family stress and coping: A decade review. Journal of Marriage and Family, 42(4), 855-871. https ://doi.org/10.2307/351829.

Melzer, B. (2011). The real costs of credit access: Evidence from the payday lending market. The Quarterly Journal of Economics, 126(1), 517-555. https://doi.org/10.1093/qje/qjq009.

Menclova, A. K. (2013). The effects of unemployment on prenatal care use and infant health. Journal of Family and Economic Issues, 34(4), 400-420. https://doi.org/10.1007/s10834-012-9339-7.

Mian, A., \& Sufi, A. (2014). House of debt: How they (and you) caused the great recession, and how we can prevent it from happening again. Chicago: The University of Chicago Press.

Mimura, Y. (2008). Housing cost burden, poverty status, and economic hardship among low-income families. Journal of Family and Economic Issues, 29, 152-165. https://doi.org/10.1007/s1083 4-007-9085-4.

Mishel, L., Bivens, J., Gould, E., \& Shierholz, H. (2012). The state of working America (12th ed.). Ithaca, N.Y.: Cornell University Press.

Mohai, P., Pellow, D., \& Roberts, J. T. (2009). Environmental justice. Annual Review of Environment and Resources, 34, 405-430. https://doi.org/10.1146/annurev-environ-082508-094348.

Moore, K. (2009). Gentrification in Black face? The return of the Black middle class to urban neighborhoods. Urban Geography, 30(2), 118-142. https://doi.org/10.2747/0272-3638.30.2.118.

Nopper, T. (2019). Digital character in "The Scored Society": FICO, social networks, and competing measurements of creditworthiness. In R. Benjamin (Ed.), Captivating technology: Race, carceral technoscience, and liberatory imagination in everyday life (pp. 170-187). Durham, NC: Duke University Press.

Park, W., \& Kim, J. (2018). How are money worries affecting middleaged, young-old, and old-old people's perceived couple relationship? Journal of Family and Economic Issues, 39(1), 34-38. https://doi.org/10.1007/s10834-017-9547-2.

Pérez, L., \& Martinez, J. (2008). Community health workers: Social justice and policy advocates for community health and wellbeing. American Journal of Public Health, 98(1), 11-14. https ://doi.org/10.2105/AJPH.2006.100842.

Pfeffer, F., Danziger, S., \& Schoeni, R. (2013). Wealth disparities before and after the Great Recession. The ANNALS of the American Academy of Political and Social Science, 650(1), 98-123. https://doi.org/10.1177/0002716213497452.

Pike, A., \& Pollard, J. (2015). Economic geographies of financialization. Economic Geography, 86(1), 29-51. https://doi.org/10.11 11/j.1944-8287.2009.01057.x.

Piketty, T. (2014). Capital in the twenty-first century. Cambridge, MA: Belknap Press.
Ponnet, K., Wouters, E., Goedemé, T., \& Mortelmans, D. (2016). Family financial stress, parenting and problem behavior in adolescents: An actor-partner interdependence approach. Journal of Family Issues, 37(4), 574-597.

Pulido, L. (2016). Flint, environmental racism, and racial capitalism. Capitalism Nature Socialism, 27(3), 1-16. https://doi. org/10.1080/10455752.2016.1213013.

Rauscher, E., \& Elliott, W. (2016). Wealth as security: Growth curve analyses of household income and net worth during a recession. Journal of Family and Economic Issues, 37(1), 29-41. https:// doi.org/10.1007/s10834-015-9442-7.

Rhine, S. L. W., Di, W., Greene, W. H., \& Perlmeter, E. (2016). Savings account ownership during the Great Recession. Journal of Family and Economic Issues, 37(3), 333-348. https://doi. org/10.1007/s10834-016-9489-0.

Rios, R., \& Zautra, A. (2011). Socioeconomic disparities in pain: The role of economic hardship and daily financial worry. Health Psychology, 30(1), 58-66. https://doi.org/10.1037/a0022025.

Robinson, C. (1983). Black Marxism: The making of the black radical tradition. Chapel Hill, NC: The University of North Carolina Press.

Romer, P. (2014). Human capital and growth: Theory and evidence. Annals of Economics and Finance, 15(1), 765-816.

Romo, L. K. (2014). “These aren't very good times”: Financial uncertainty experienced by romantic partners in the wake of an economic downturn. Journal of Family and Economic Issues, 35(4), 477-488. https://doi.org/10.1007/s10834-014-9389-0.

Rothstein, R. (2017). The color of law: A forgotten history of how our government segregated America. New York: Liveright Publishing Corp.

Schieman, S., \& Young, M. (2011). Economic hardship and family-towork conflict: The importance of gender and work conditions. Journal of Family and Economic Issues, 32, 46-61. https://doi. org/10.1007/s10834-010-9206-3.

Serido, J., Lawry, C., Li, G., Conger, K. J., \& Russell, S. T. (2014). The associations of financial stress and parenting support factors with alcohol behaviors during young adulthood. Journal of Family and Economic Issues, 35(3), 339-350. https://doi.org/10.1007/ s10834-013-9376-x.

Shapiro, T. (2017). Toxic inequality: How America's wealth gap destroys mobility, deepens the racial divide, and threatens our future. New York: Basic Books.

Sharkey, P., Torrats-Espinosa, G., \& Takyar, D. (2017). Community and the crime decline: The causal effect of local nonprofits on violent crime. American Sociological Review, 82(6), 1214-1240. https://doi.org/10.1177/0003122417736289.

Shore, N., Ford, A., Wat, E., Brayboy, M., Isaacs, M.-L., Park, A., et al. (2015). Community-based review of research across diverse community contexts: Key characteristics, critical issues, and future directions. American Journal of Public Health, 105(7), 1294-1301. https://doi.org/10.2105/AJPH.2015.302588.

Showalter, K. (2016). Women's employment and domestic violence: A review of the literature. Aggression and Violent Behavior, 31, 37-47. https://doi.org/10.1016/j.avb.2016.06.017.

Small, M. L., \& McDermott, M. (2006). The presence of organizational resources in poor urban neighborhoods: An analysis of average and contextual effects. Social Forces, 84(3), 1697-1724.

Stein, C. H., Hoffmann, E., Bonar, E. E., Leith, J. E., Abraham, K. M., Hamill, A. C., et al. (2013). The United States economic crisis: Young adults' reports of economic pressures, financial and religious coping and psychological well-being. Journal of Family and Economic Issues, 34(2), 200-210. https://doi.org/10.1007/ s10834-012-9328-x.

Sweet, E., Nandi, A., Adam, E. K., \& McDade, T. W. (2013). The high price of debt. Household financial debt and its impact on mental and physical health. Social Science \& Medicine, 91, 94-100. 
Taylor, K.-Y. (2019). Race for profit: How banks and the real estate industry undermine black homeownership. Chapel Hill, NC: The University of North Carolina Press.

Thorne, D. (2010). Extreme financial strain: Emergent chores, gender inequality and emotional distress. Journal of Family and Economic Issues, 31(2), 185-197. https://doi.org/10.1007/s1083 4-010-9189-0.

Tobe, E., Ames, B. D., \& Carolan, M. (2016). Looking back: The experiences of four midwest families after receiving foreclosure counseling services. Journal of Family and Economic Issues, 37(3), 383-394. https://doi.org/10.1007/s10834-016-9495-2.

Trattner, W. (1999). From poor law to welfare state: A history of social welfare in America (6th ed.). New York: The Free Press.

Valentino, S. W., Moore, J. E., Cleveland, M. J., Greenberg, M. T., \& Tan, X. (2014). Profiles of financial stress over time using subgroup analysis. Journal of Family and Economic Issues, 35(1), 51-64. https://doi.org/10.1007/s10834-012-9345-9.

Vesely, C. K., Goodman, R. D., Ewaida, M., \& Kearney, K. B. (2015). A better life? Immigrant mothers' experiences building economic security. Journal of Family and Economic Issues, 36(4), 514530. https://doi.org/10.1007/s10834-014-9422-3.

Walsdorf, A., Jordan, L., McGeorge, C., \& Caughy, M. (2020). White supremacy and the web of family science: Implications of the missing spider. Journal of Family Theory \& Review. https://doi. org/10.1111/jftr.12364.

Wang, J. (2018). Carceral capitalism. Cambridge, MA: MIT Press.

Watson, N., \& Hunter, C. (2015). Anxiety and depression among African American women: The costs of strength and negative attitudes toward psychological help-seeking. Cultural Diversity and Ethnic Minority Psychology, 21(4), 604-612.

Western, B., \& Rosenfeld, J. (2011). Unions, norms, and the rise in U.S. wage inequality. American Sociological Review, 76(4), 513-537. https://doi.org/10.1177/0003122411414817.

Woods-Giscombé, C. L., \& Lobel, M. (2008). Race and gender matter: A multidimensional approach to conceptualizing and measuring stress in African American women. Cultural Diversity and Ethnic Minority Psychology, 14(3), 173-182. https://doi. org/10.1037/1099-9809.14.3.173.

Wright, E. O. (2018). The continuing relevance of the Marxist tradition for transcending capitalism. Triple C: Communication, Capitalism, \& Critique.. https://doi.org/10.31269/triplec.v16i2.968.

Publisher's Note Springer Nature remains neutral with regard to jurisdictional claims in published maps and institutional affiliations.

Terri Friedline is an Associate Professor of Social Work at the University of Michigan. Her research focuses on financial system reforms and consumer protections. She holds an MSW and $\mathrm{PhD}$ from the University of Pittsburgh School of Social Work, and is an appointed member of the Consumer Financial Protection Bureau's (CFPB) Academic Research Council.

Zibei Chen is an Assistant Professor at the University of Southern Mississippi School of Social Work. Her research focuses on understanding financial behaviors and decision making and interventions that promote financial inclusion and economic security for low-to-moderate income individuals and families. She holds an MSW and $\mathrm{PhD}$ from Louisiana State University, and received postdoc training at the Center on Assets, Education, and Inclusion housed in the University of Michigan School of Social Work.

So'Phelia Morrow is a doctoral student in the joint $\mathrm{PhD}$ program between Social Work and Sociology at the University of Michigan. Her research interests include understanding the relationship between wealth health among Black women. She holds an MSW ('17) from the University of Michigan School of Social Work and an MPH ('17) from the University of Michigan School of Public Health. So'Phelia is also a Rackham Merit Fellow. 